\title{
Improvements in Electric Power Potential Generation from Plants Microbial Fuel
}

\section{Cells}

Melisa Acosta-Coll ${ }^{1}$, Adalberto Ospino-Castro ${ }^{2}$, Stalin Carbonell-Navarro ${ }^{2}$, Jaider EscobarDuque $^{2}$, Rafael Peña-Gallardo ${ }^{3}$

${ }^{1}$ Department of Computer Science and Electronic, Universidad de la Costa. Street 58 \# 55 - 66, Barranquilla, Colombia

${ }^{2}$ Department of Energy, Universidad de la Costa. Street 58 \# 55 - 66, Barranquilla, Colombia

${ }^{3}$ Engineering faculty, Universidad Autónoma de San Luis Potosí. Álvaro Obregón \#64, Col. Centro, San Luis Potosí, Mex

Corresponding: Melisa Acosta-Coll, macosta10@cuc.edu.co

\begin{abstract}
Plants Microbial Fuel Cells (PMFC) is a new technology that generates electricity in a renewable, clean and sustainable way. In spite of these advantages, it still faces limitations in power generation and current density, reaching lower production values than other renewable technologies. Different studies maintain that the high resistivity of the cathode is the main limitation in the generation of energy; therefore, non-metallic materials to obtain a better performance are replacing the metallic electrodes. The implementation of these materials applied to PMFC requires a complex interdisciplinary work. Through three experimental tests using metallic electrodes for the extraction of electrons, this research study shows that the treatment of the substrate with natural materials, the volume plant roots, and substrate temperature and humidity control have a significant influence in the increase of the electric potential and the generated current.
\end{abstract}

\section{Keywords}

Plants-Microbial Fuel Cells; clean energy; electric potential; power output; resistivity 


\section{Introduction}

The effects of climate change, the depletion of fossil fuels and the high demand for energy have caused a search for alternatives to produce renewable, sustainable and reliable electricity, having minimal environmental impact [1][2]. Currently, there are non${ }^{\mathrm{i}}$ conventional energy sources, yet with a degree of pollution when operating, increasing the emission of greenhouse gases [3][4].

One of these alternatives for the generation of electrical energy without emission of contaminants has been the implementation of Microbial Fuel Cells (MFC) [5]-[9]. MFC use microorganisms for the oxidation of organic matter and substrates of the surface by means of a process of anaerobic respiration to generate bioelectricity. Still, power generation and current density are low compared to other non-conventional energy sources $[10]-[12]$.

In order to increase generation power, a new method named Plants-Microbial Fuel Cell (PMFC) emerged [13]. Through the PMFC method the solar energy trapped by plants is converted into electricity by means of bacterial actions in plants' rhizosphere, which is the part of the soil immediately adjacent to the living roots and under their direct influence [14]. Electron extraction is possible by placing the anode next to the roots and then transferring them to the cathode through an external circuit where the electricity is obtained. At the cathode, electrons are collected through oxygen reduction [15]-[21].

This method can generate continuous energy and operated at any location, however, there are some challenges in power generation that need to be met before its real application.

One of the factors that most affects the generation capacity of this technology is the electrode material, which must have a good electrical conductivity and low resistance [5] 
[22]. Cathode performance is considered the main limitation since it is the main source of internal resistance [23]. Different materials have been used in the cathodes to maximize the generation capacity. Table 1 shows a summary with non-metallic materials used to improve cathode efficiency and obtain more power (W/m2), current (mA) and voltage (mV).

Table 1 Non-metallic materials used to improve cathode efficiency

\begin{tabular}{|l|l|l|l|}
\hline \multicolumn{1}{|c|}{ Material } & \multicolumn{1}{c|}{$\begin{array}{c}\text { Max power } \\
\text { density }\end{array}$} & $\begin{array}{c}\text { Max current } \\
\text { density }\end{array}$ & \multicolumn{1}{c|}{ Max voltage } \\
\hline $\begin{array}{l}\text { Activated carbon } \\
\text { fiber felt (ACFF) } \\
{[24]}\end{array}$ & $0.315 \mathrm{~W} / \mathrm{m}^{2}$ & $1.67 \times 10^{-3} \mathrm{~mA} / \mathrm{m}^{2}$ & $679 \mathrm{mV}$ \\
\hline $\begin{array}{l}\text { Tubular }(\mathrm{ACFF}) \\
{[24]}\end{array}$ & $0.784 \mathrm{~W} / \mathrm{m}^{2}$ & $3170 \mathrm{~mA} / \mathrm{m}^{2}$ & $716 \mathrm{mV}$ \\
\hline Graphite felt [24] & $0.539 \mathrm{~W} / \mathrm{m}^{2}$ & $3145 \mathrm{~mA} / \mathrm{m}^{2}$ & $742.3 \mathrm{mV}$ \\
\hline $\begin{array}{l}\text { ACFF granules } \\
(1 \mathrm{~cm})[25]\end{array}$ & $0.667 \mathrm{~W} / \mathrm{m}^{2}$ & $3340 \mathrm{~mA} / \mathrm{m}^{2}$ & $658 \mathrm{mV}$ \\
\hline
\end{tabular}

Other techniques have been used to increase PMFC power generation, as the one implemented by the University of Engineering and Technology (UTEC) that captured electricity through a group of microorganisms called Geobacter. These microorganisms, during the normal process of plant growth, help release electrons through electrodes located in the plant's substrate increasing the power output [26].

Likewise, other studies used different types of plants [27], variation of anode position with respect to the distance of the roots [28], studies on the effect of sunlight [29], European institutes work towards a maximum electrical production of $3 \mathrm{~W} / \mathrm{m} 2$ [30].

To face this problem, this study was conducted to improve the efficiency of bioelectricity production through Plants Microbial Fuel Cells (PMFC), combining different natural materials, tropical plants, and circuit arrangements in a black sand substrate. The 
combination leading to a greater generation capacity, without causing damage to the plant, was determined through three tests. Metal electrodes of aluminum and copper were used in all combinations.

\section{Materials and methods}

\subsection{Experimental setup}

A metallic aluminum net, as a negative pole, and a spiral of bare copper wire, as a positive pole, were introduced into black earth substrates to measure the electrical potential and the current generated. Through three tests, the substrates were combined with materials such as activated carbon, charcoal, saline, seawater, compost, and different types of plants to determine the combination that generates the most electrical and current potential.

Each combination was built through four steps. First, a layer of black sand moistened with drinking water is added to the base of the pot. Second, the aluminum mesh is placed on the first layer of sand as a negative pole. Third, a second layer of sand is added to the mesh and a copper spiral is inserted, which is the positive pole. Finally another layer of treated sand is placed and the plants are sown. Figure 1 shows the circuit diagram described. 


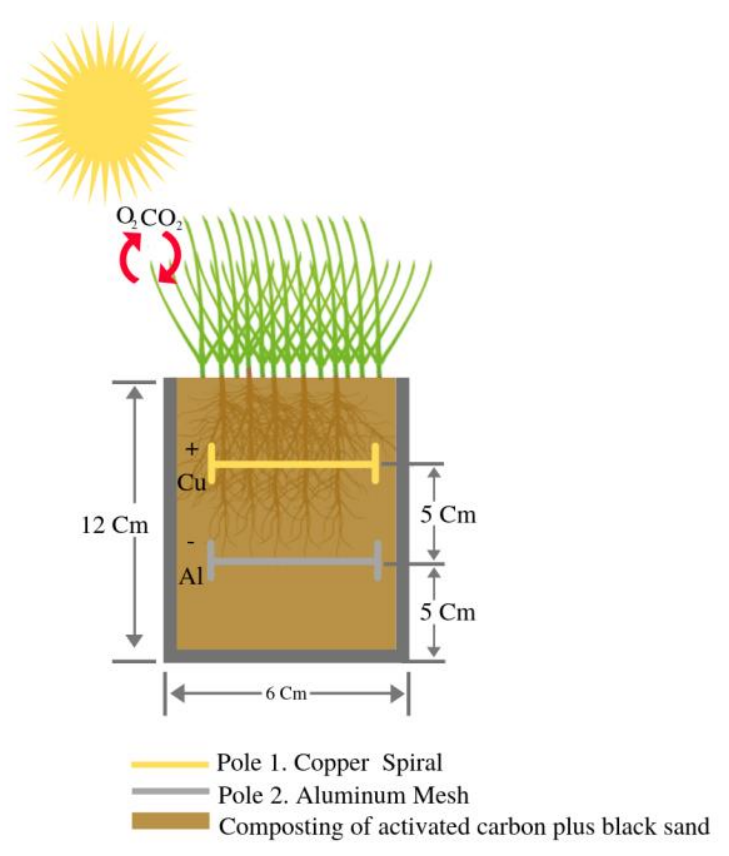

Figure 1 Circuit design for each combination.

\section{Experiments}

\section{Test 1: Voltage measurement}

For the first test, 5 combinations of black sand substrate and natural materials such as activated carbon, charcoal and saline solution were made with Chlorophytum comosum plants. For seven days, the voltage of each combination was measured with a 24-hour interval, to identify which combination generates the greatest electrical potential, causing no damage to the plants. Table 2 shows the combinations made with the plant and Table 3 shows the quantities of soil, water and materials used for each combination. 
Table 2 Combinations of substrate with plants

\begin{tabular}{|c|c|}
\hline Combinations & Materials \\
\hline 1 & Black sand + water+plants \\
\hline 2 & Black sand + activated charcoal+ water+plants \\
\hline 3 & Black sand + charcoal+ water+plants \\
\hline 4 & Black sand+activated charchoal+saline solution+plants \\
\hline 5 & Black sand+saline solution+pants \\
\hline
\end{tabular}

Table 3 Materials used in the combinations

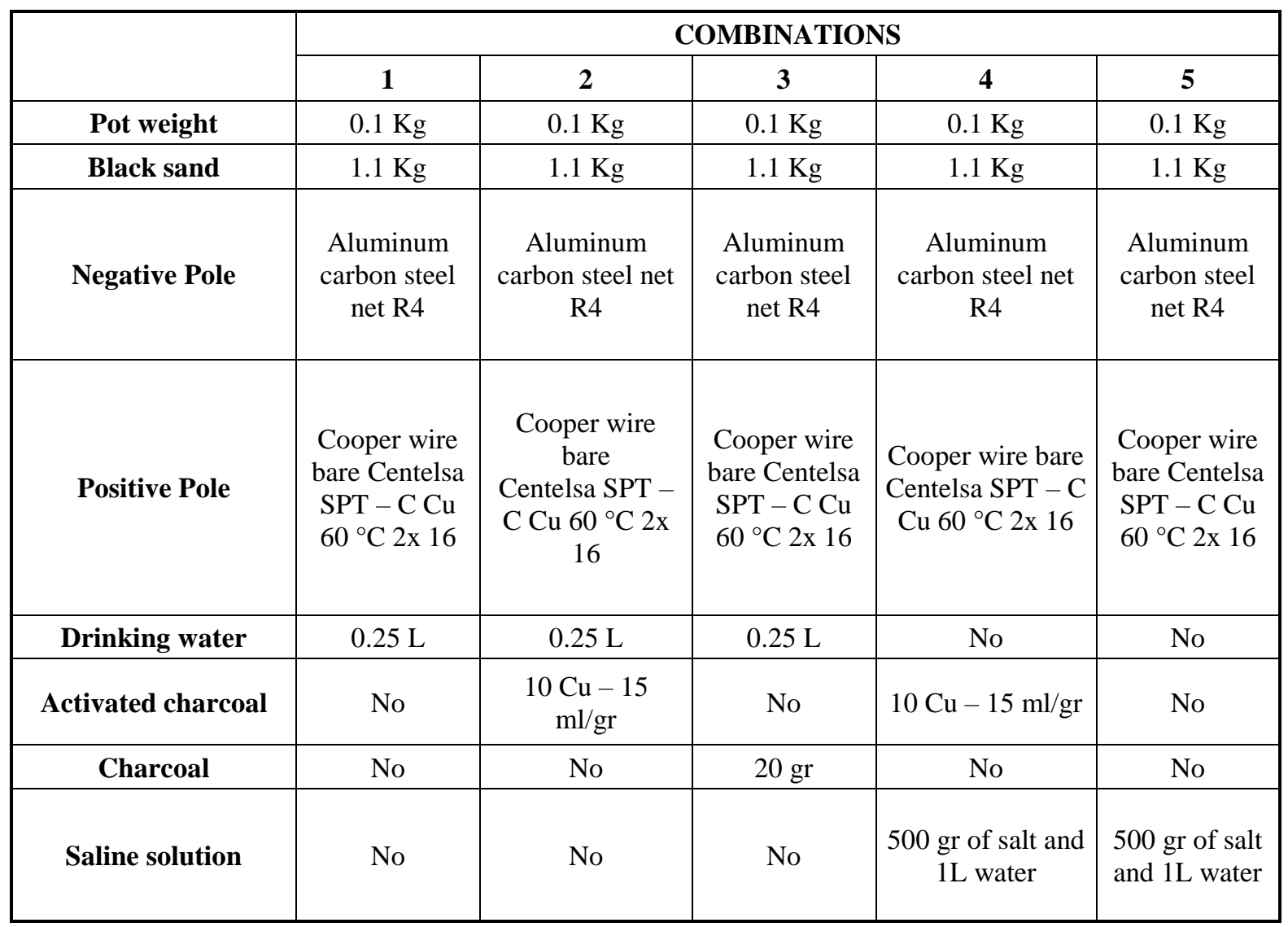

Combinations 2 and 4 used activated carbon, which is formed of a developed internal porous structure and can reach highly crystalline absorption rates. Its structure contains 
properties similar to those of graphite, catalyzing chemical reactions and storing electrical charges, with a high electrical conductivity [31][32].

Charcoal was considered in these tests to measure its incidence in voltage increase, because it is one of the fertilizers with greater use in planting and caring for plants, which increases crops' productivity [33][34]. It also stops the release of volatile carbon in the environment and is antibacterial and antiparasitic for plants. It also favorably influences the development of microorganisms that increase oxygen in the roots of plants [33][34]. Another advantage of charcoal is that it contributes to the increase in soil permeability by retaining moisture, preventing the elution of soil nutrients, especially in intensive agriculture fields [35][36]

Finally, saline solution was used in combinations 4 and 5 in order to increase the conductivity and achieve an increase in electrical potential. Salts dissolved in water are decomposed into positively and negatively charged ions. In solutions with a higher salinity, the amount of dissolved ions is greater and thus increases their conductivity [37], [38].

\section{Test 2: Voltage increase}

Once the substrate combination that generates higher voltage and does not cause deterioration in the plants was determined, two circuits were built to increase energy production. In the first circuit, 5 pots (model 1) were placed connected in series with the selected combination and the voltage was measured for 8 days. Figure 2 shows the construction of the series circuit with the pots. This model was used according to the theory of electrical circuits, where the total voltage is the sum of all in it, and circuit current remains constant [39]. 


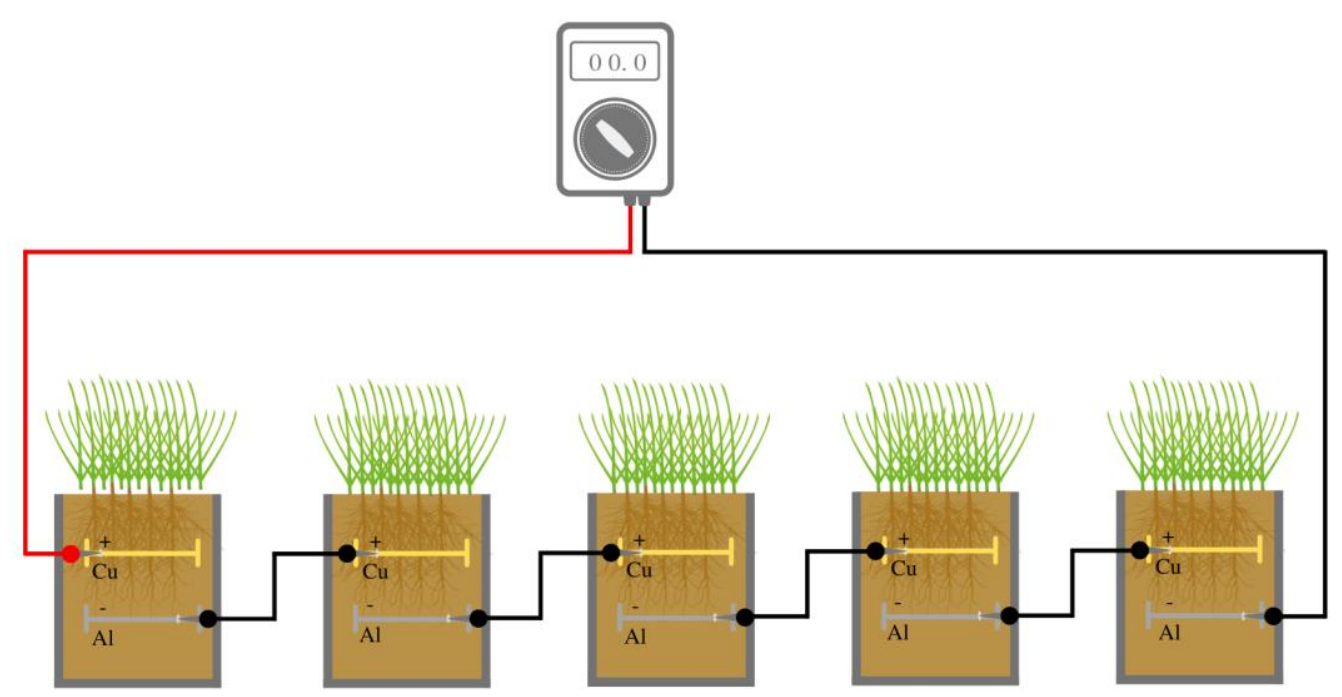

Figure 2 Series circuit connection

For the second circuit, model 2 of the pot was used, combining 3 types of plants ( 1 type Chlorophytum comosum, 1 type Tradescantia pallida, and 1 type Caladium) in order to determine the influence of root volume on the increase in voltage. The voltage was measured during 8 days in a 24-hour interval, controlling plant humidity every 30 hours. Figure 3 shows the pot (model 2) with the combination of different plants. 


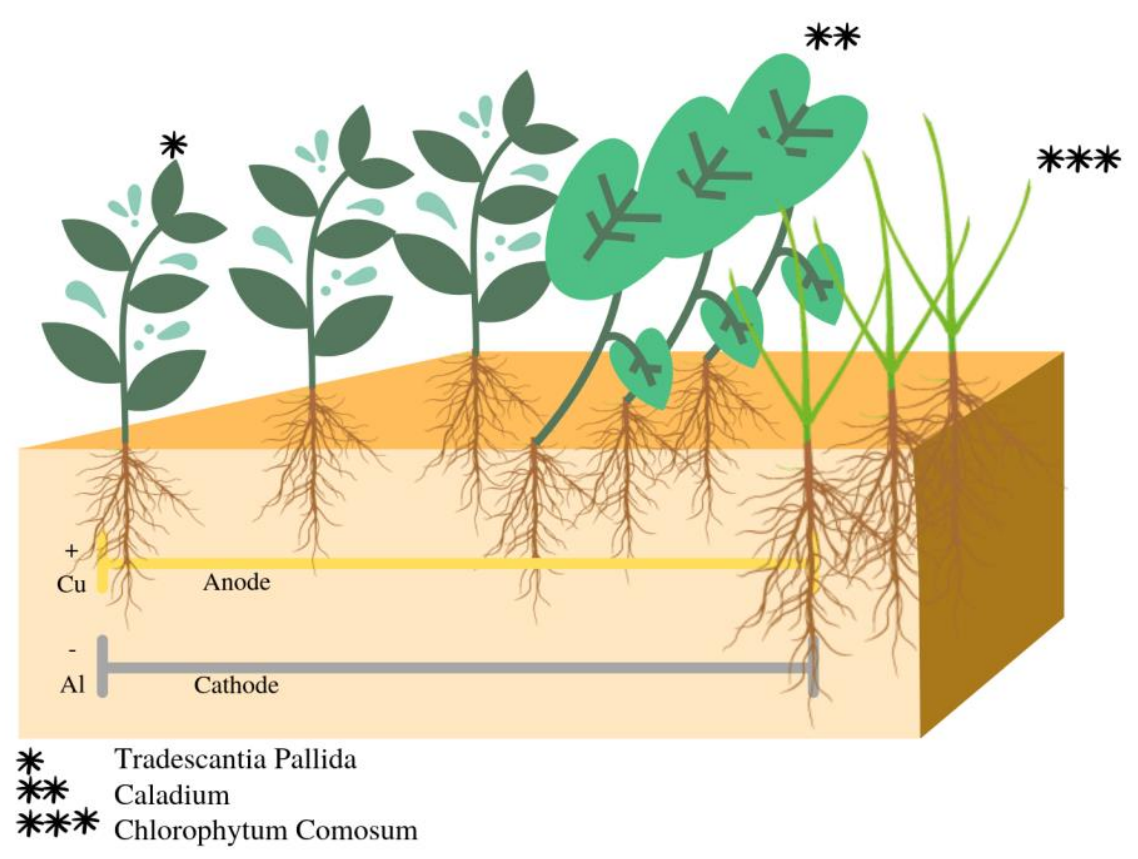

Figure 3 Pot with different plants

\section{Test 3: Increase of power generation}

Once the circuit that generated the highest voltage of test 2 was selected, three new combinations were built to obtain an increase in current, without decreasing the voltage, and therefore achieving an increase in power generation. Model 2 of the pot was used with more Chlorophytum comosum plants, combining the substrate with elements such as compost, warm water, and seawater. Table 4 gathers the combinations made.

Table 4 Combinations for current increase

\begin{tabular}{|c|c|}
\hline Combinations & Materials \\
\hline 1 & Black sand + water+compost+plants \\
\hline 2 & Black sand + warm water+ plants \\
\hline 3 & Black sand + sea water+ plants \\
\hline
\end{tabular}


The compost is used to nourish and obtain a higher concentration of organic matter excreted by the plant and thus collects it using electrodes [40][41][42]. The warm water (drinking water at $45^{\circ} \mathrm{C}-50^{\circ} \mathrm{C}$ ) was used to keep the plant in a constant temperature state due to differences in environment and substrate temperatures [43][29]. Seawater was used due to the large amount of minerals, conductivity properties, high levels of salinity and $\mathrm{pH}$, which generates an increase in the current [44][45]. For this test, $250 \mathrm{ml}$ of water were added daily for a period of 5 days, measuring the voltage and current generated by each combination using a resistance of $270 \Omega$.

\section{Results and discussion}

\subsection{Test 1}

Using aluminum and copper electrodes, when combining the sand substrate and plants with materials such as activated carbon, charcoal and solution, voltage values higher than $490 \mathrm{mV}$ were obtained. Figure 4 presents the results of the voltage measurements of the combinations in Table 2. 


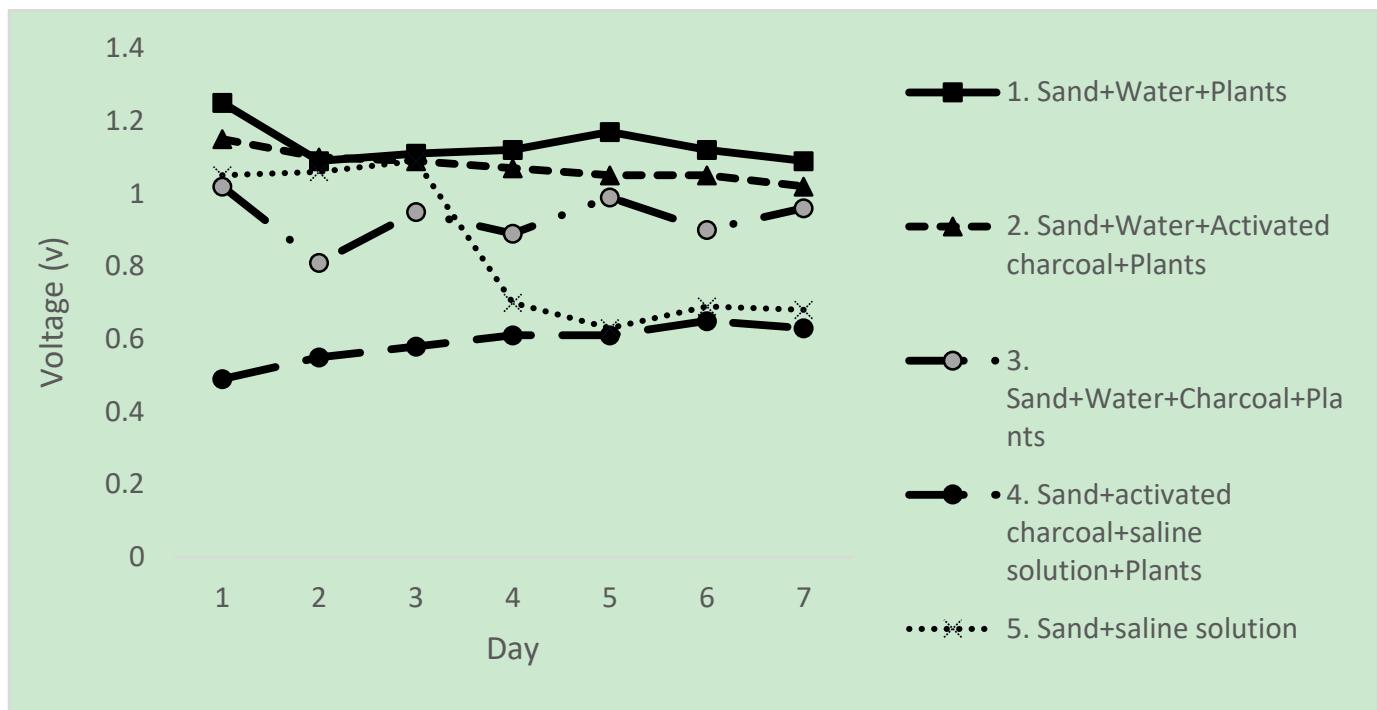

Figure 4 Results test 1

The combination that obtained the highest voltage value is combination 1 (Black Sand + potable water + plants $)$, followed by combination $2($ Black Sand + Active Carbon + potable water + plants). The combination that obtained the lowest voltage value was combination 4 (Black Sand + Active Carbon + saline + plants).

Regarding the state of the plant, it did not show deterioration in combinations $1,2,3$ and 4 , however, although it obtained a higher voltage value than in combination 4, the plant deteriorated completely in combination 5 (Black Sand + saline + plants). Therefore, combination 1 was selected to perform the voltage and current increase tests. The saline solution is discarded for future tests since it generates total deterioration in the plants.

For voltage measurement, electrodes must be distant from each other to obtain a measure without variations, since there are distortions when they are placed close together. 


\subsection{Test 2}

Figure 5 shows the results of the circuits developed to increase the voltage. The first is a series circuit consisting of 5 pots (model 1) with Chlorophytum comosum plants. The second circuit is a pot (model 2) with different types of plants with higher root volume per square meter.

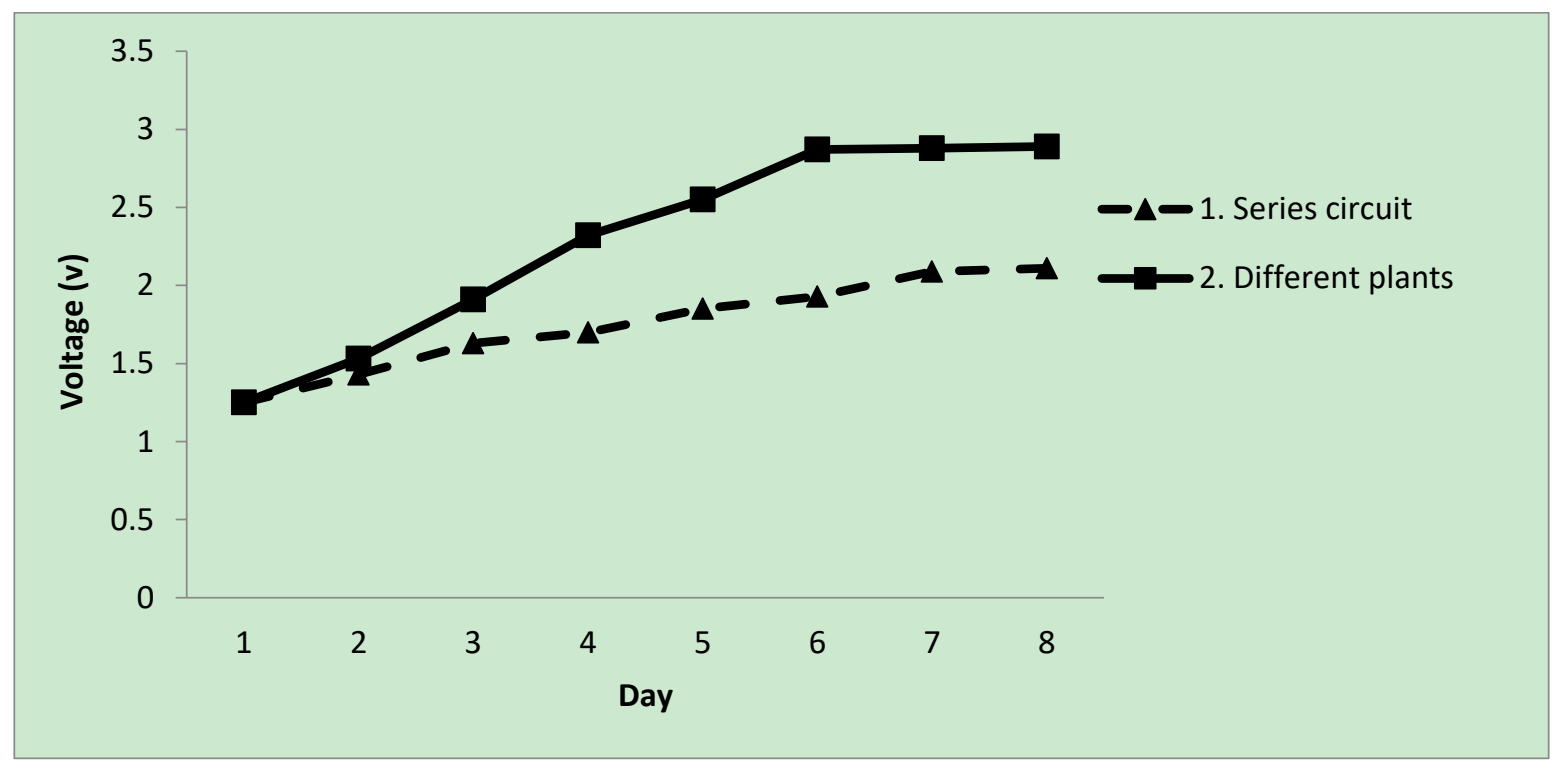

Figure 5 Results test 2

According to the results of test 2, the circuit that obtained the greatest increase in voltage is formed by different types of plants and a greater number of roots per square meter. This shows that the generation of energy does not depend clearly on the type of plant used, but rather that the plant must have the necessary nutrients to perform the photosynthetic process, and a certain root volume, i.e., the greater the roots, the greater the generation of electric power. This circuit was selected to perform the current increase test. 


\subsection{Test 3}

According to the results obtained in test 2 , the voltage is proportional to the number of roots per square meter. Therefore, in test 3, a greater number of Chlorophytum comosum roots were planted in model 2 pots.

Then, to obtain an increase in the generation power, the black sand substrate was combined with materials such as compost, warm water, and seawater. Figure 6 compares voltage, and Figure 7, current values.

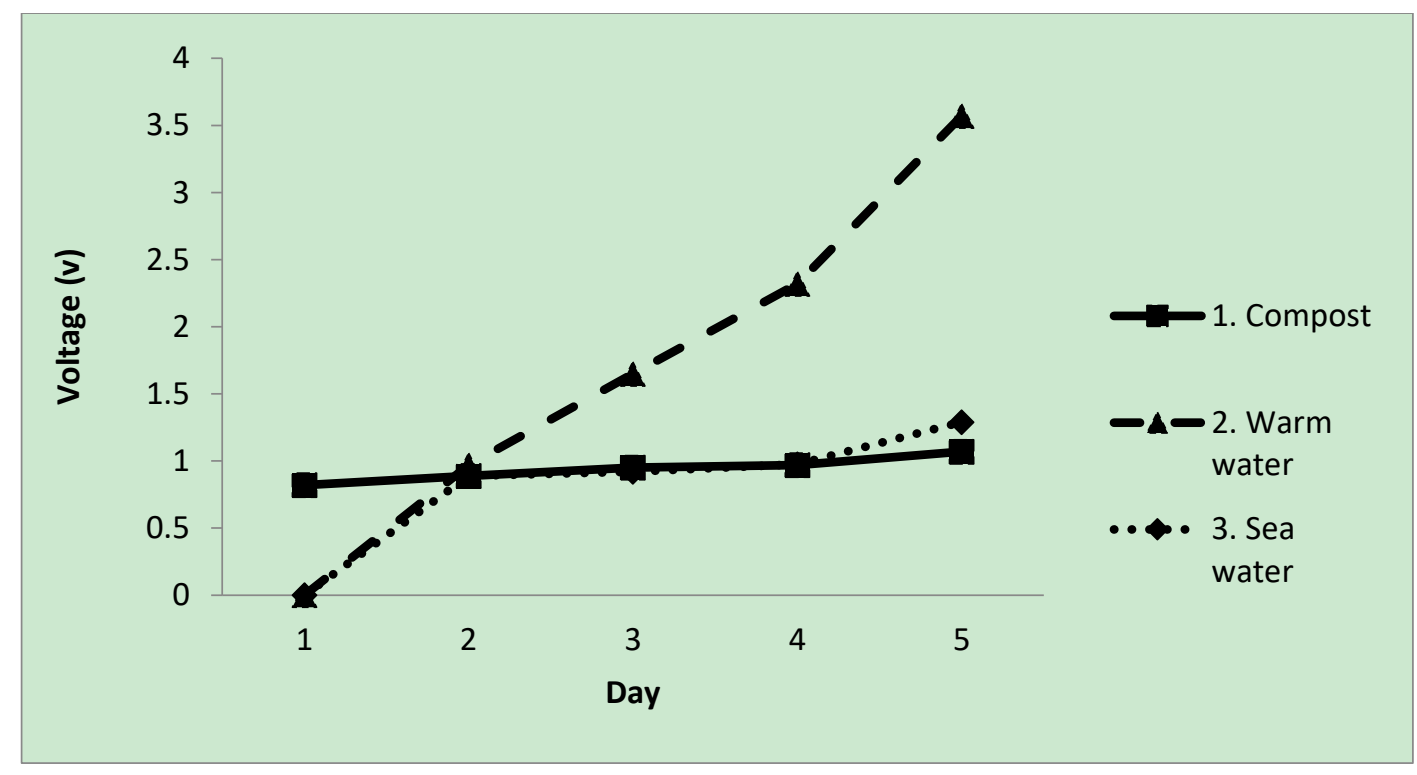

Figure 6 Voltage values test 3 


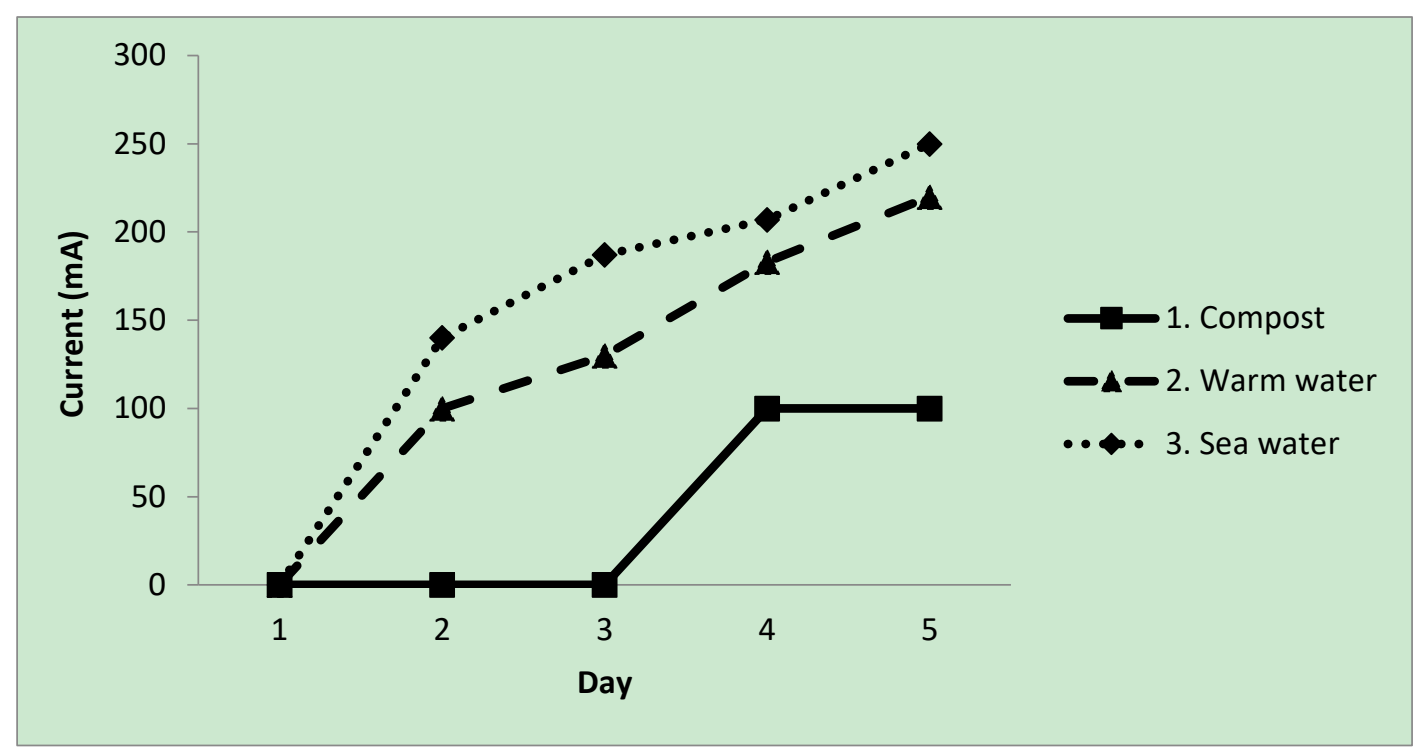

Figure 7 Current values test 3

It can be seen in Figure 6 that the circuit that obtained the highest level of voltage is the one where room-temperature water was replaced by warm water. Although the circuit with compost obtained a constant value of voltage, these were lower. The circuit with seawater obtained the lowest voltage values during days 1,2 and 3, but, during days 4 and 5, it obtained better results than the circuit with compost.

Regarding current (figure 7), the circuit that generated the highest levels was that of seawater. However, the plant showed deterioration in its leaves. The compost circuit only recorded current on days 4 and 5 , but obtained the lowest values.

Figure 8 shows the results for output power obtained in this test expressed in $\mathrm{W} / \mathrm{m} 2$. 


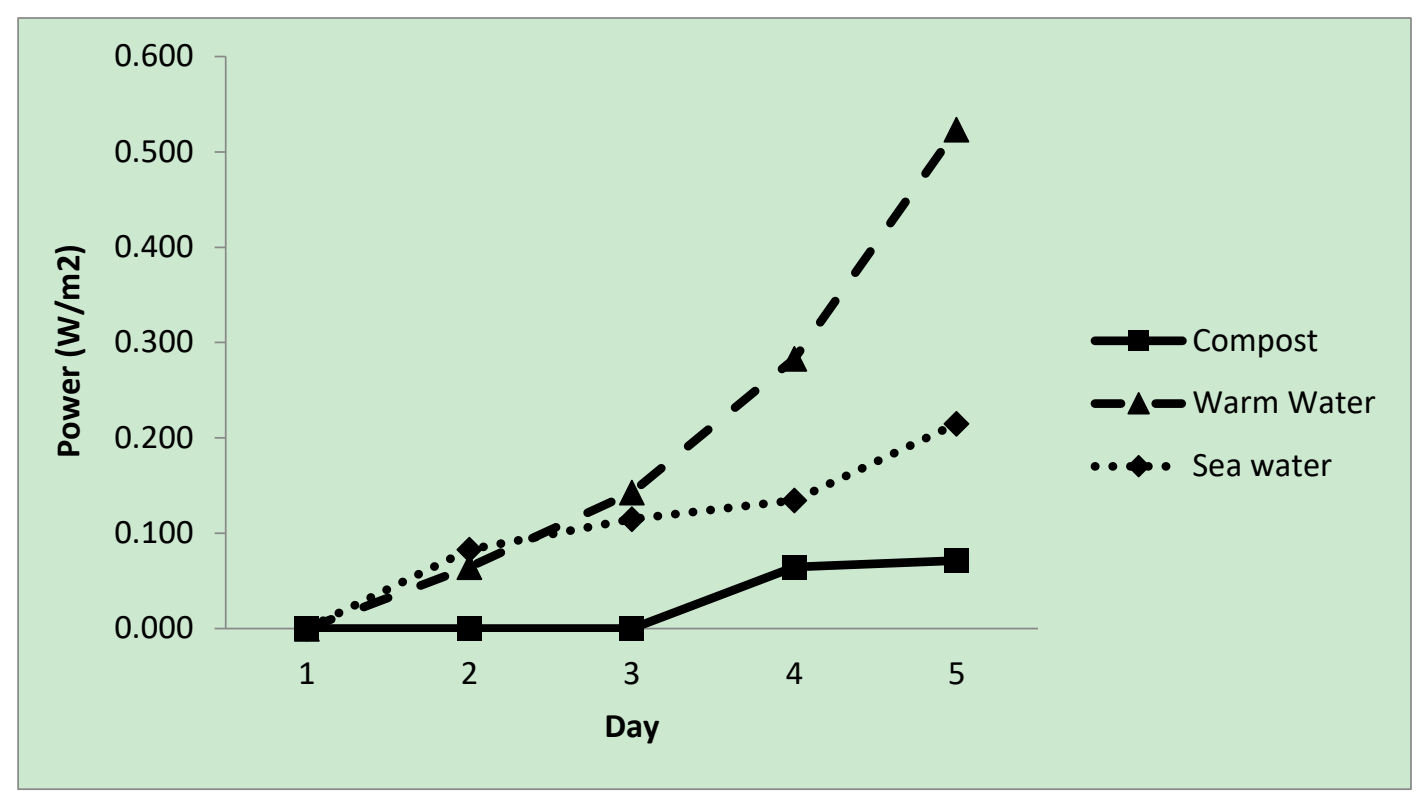

Figure 8 Power output test 3

The circuit with compost did not generate current during days 1,2 and 3, and power values were recorded only on days 4 and 5 ranging between $0.065 \mathrm{~W} / \mathrm{m} 2-0.071 \mathrm{~W} / \mathrm{m} 2$. Although the combination with seawater generated higher current values, the voltage decreased and caused plant deterioration.

Therefore, the combination that obtained the highest performance in generation capacity without damaging the plant is the combination of black sand substrate in model 2 pots, with more roots, and hydrated with warm water. The power generation range obtained was 0.065 $\mathrm{W} / \mathrm{m} 2-0.524 \mathrm{~W} / \mathrm{m} 2$. This is due to the fact that most biological processes are accelerated at high temperatures, that is, rapid growth or fruit production can be achieved [46][47][48]. Some effects manifest themselves in the short term while others will do so in the long term. The balance of plant assimilation, for instance, is quickly influenced by temperature; yet, floral induction will require more time. Hydrating the plants with warm water is beneficial; 
still, the temperature should be controlled since using it too hot can lead to deterioration or death. Temperatures between $43^{\circ} \mathrm{C}-55^{\circ} \mathrm{C}$ will help accelerate growth [48][49][50]

Table 5 presents a summary of the maximum voltage values obtained in each test. Likewise, the current value and maximum power obtained in test 3 that did not cause deterioration to the plant.

Table 5 Maximum voltage values

\begin{tabular}{|c|c|c|c|}
\hline & Test1 & Test 2 & Test 3 \\
\cline { 2 - 4 } & Black sand+plantas+water & Different plants & $\begin{array}{c}\text { Black sand+more } \\
\text { plants+warm water }\end{array}$ \\
\hline Max. Voltage (V) & 1.09 & 2.89 & 3.57 \\
\hline Max. Current (mA) & N/A & N/A & 220 \\
\hline Max. Power (W/m2) & N/A & N/A & 0.524 \\
\hline
\end{tabular}

The development of these experiments shows that, in order to increase the power of bioelectricity generation through PMFC, the efficiency of the cathode is determining, as well as variables such as number of roots per square meter, water temperature, and humidity of the substrate, which influence the increase of the generation power in PMFC.

\section{CONCLUSIONS}

1. The generation of bioelectricity through the Plants Microbial Fuel Cells (PMFC) method is an alternative of a sustainable nature with zero emissions to the environment. Through a natural interaction of the plants with the soil, electrical energy can be obtained. However, the power output values are still low compared to other types of green energy generation. Therefore, this technology continues to be of great investigative interest in the quest to increase and maintain the fundamental 
electrical parameters of an electrical system constant (voltage, current, power), in order to make it reliable for large-scale use.

2. This investigation led to different tests to determine which natural materials have influence on the increase of power output. Likewise, the influence of the number of roots per square meter in the increase of these values was checked. Results show that the process of generating electricity through PMFC is directly related to the number of roots that a plant has because it is the place where there is the highest concentration of microbial activity. The plant through the process of excretion of nutrients provides the bacteria with organic material to break it down, resulting in the release of electrons. Therefore, the more roots the plant possesses, the more nutrients it will provide to the bacteria, increasing the generation of electricity.

3. Some of the natural materials used to treat the substrate in this research are activated carbon, charcoal, compost, seawater, and warm water. According to the results, the factor of greatest influence for the generation of bioelectricity is the degree of humidity to which the plant is exposed. It is recommended to maintain constant humidity not only to avoid the deterioration of the plant, but the water allows an adequate generation of food and produces greater microbial activity.

4. In addition to maintaining the plant with constant humidity, it was found that keeping temperatures just above natural environment achieved an increase in electrical conductivity without damaging the plant. Seawater and saline solutions achieved higher current levels, however, their use is ruled out since they cause plant death or deterioration. 


\section{REFERENCES}

[1] M. Acosta-Coll, F. Ballester-Merelo, M. Martinez-Peiró, and E. De la Hoz-Franco, "Real-time early warning system design for pluvial flash floods—a review," Sensors (Switzerland), vol. 18, no. 7, 2018.

[2] J. J. C. Eras, A. S. Gutiérrez, D. G. Lorenzo, J. B. C. Martínez, L. Hens, and C. Vandecasteele, "Bridging universities and industry through cleaner production activities. Experiences from the Cleaner Production Center at the University of Cienfuegos, Cuba,” J. Clean. Prod., vol. 108, pp. 873-882, 2015.

[3] S. S. Oncel, "Green energy engineering: Opening a green way for the future," $J$. Clean. Prod., vol. 142, pp. 3095-3100, 2017.

[4] C. A. Robles-Algarín, J. A. Taborda-Giraldo, and A. J. Ospino-Castro, "Procedimiento para la Selección de Criterios en la Planificación Energética de Zonas Rurales Colombianas," Inf. Tecnol., vol. 29, no. 3, pp. 71-80, 2018.

[5] M. Rahimnejad, A. Adhami, S. Darvari, and A. Zirepour, "Microbial fuel cell as new technology for bioelectricity generation: A review," Alexandria Eng. J., vol. 54, no. 3, pp. 7545-756, 2015.

[6] C. Santoro, C. Arbizzani, B. Erable, and I. Ieropoulos, "Microbial fuel cells: From fundamentals to applications. A review," J. Power Sources, vol. 356, pp. 225-244, 2017.

[7] T. Tommasi and G. Lombardelli, "Energy sustainability of Microbial Fuel Cell (MFC): A case study," J. Power Sources, vol. 356, pp. 438-447, 2017. 
[8] S. G. A. Flimban, I. M. I. Ismail, T. Kim, and S.-E. Oh, “Overview of Recent Advancements in the Microbial Fuel Cell from Fundamentals to Applications: Design, Major Elements, and Scalability,” Energies, vol. 12, no. 17, 2019.

[9] S. G. A. Flimban, I. M. I. Ismail, T. Kim, and S.-E. Oh, “Overview of Recent Advancements in the Microbial Fuel Cell from Fundamentals to Applications: Design, Major Elements, and Scalability,” Energies, vol. 12, no. 17, 2019.

[10] M. Li et al., "Microbial fuel cell ( MFC ) power performance improvement through enhanced microbial electrogenicity," Biotechnol. Adv., vol. 36, no. 4, pp. 1316-1327, 2018.

[11] A. J. Slate, K. A. Whitehead, D. A. C. Brownson, and C. E. Banks, "Microbial fuel cells : An overview of current technology," Renew. Sustain. Energy Rev., vol. 101, no. November 2018, pp. 60-81, 2019.

[12] P. Pandey, V. N. Shinde, R. L. Deopurkar, S. P. Kale, S. A. Patil, and D. Pant, "Recent advances in the use of different substrates in microbial fuel cells toward wastewater treatment and simultaneous energy recovery," Appl. Energy, vol. 168, pp. 706-723, 2016.

[13] S. Prasann, G. Gurram, and E. Engineering, "Technology by Plant-e from Living Plants and Bacteria,” pp. 146-151, 2017.

[14] R. Regmi, R. Nitisoravut, and J. Ketchaimongkol, “A decade of plant-assisted microbial fuel cells: looking back and moving forward," Biofuels, vol. 9, no. 5, 2018.

[15] M. Rossi, A. Iannaci, P. Tosato, and D. Brunelli, "Let the microbes power your sensing display," Proc. IEEE Sensors, vol. 2017-Decem, pp. 1-3, 2017. 
[16] M. A. Moqsud, J. Yoshitake, Q. S. Bushra, M. Hyodo, K. Omine, and D. Strik, "Compost in plant microbial fuel cell for bioelectricity generation," Waste Manag., vol. 36, pp. 63-69, 2015.

[17] R. A. Timmers, D. P. B. T. B. Strik, H. V. M. Hamelers, and C. J. N. Buisman, "Electricity generation by a novel design tubular plant microbial fuel cell," Biomass and Bioenergy, vol. 51, pp. 60-67, 2013.

[18] C. Y. Guan, Y. H. Tseng, D. C. W. Tsang, A. Hu, and C. P. Yu, "Wetland plant microbial fuel cells for remediation of hexavalent chromium contaminated soils and electricity production," J. Hazard. Mater., vol. 365, no. February 2018, pp. 137-145, 2019.

[19] BBC MUNDO, "El invento chileno para recargar el celular conectándolo a una planta - BBC News Mundo,” 01 septiembre , 2015. .

[20] Amanda Froelich, “This Incredible System Generates Electricity From Living Plants - True Activist," August 4, 2015. .

[21] Nanda Scharama, "How to generate electricity from living plants | World Economic Forum," 05 August, 2015. .

[22] B. E. Logan et al., "Microbial fuel cells: Methodology and technology," Environ. Sci. Technol., vol. 40, no. 17, pp. 5181-5192, 2006.

[23] G. W. Chen, S. J. Choi, T. H. Lee, G. Y. Lee, J. H. Cha, and C. W. Kim, “Application of biocathode in microbial fuel cells: cell performance and microbial community," Appl. Microbiol. Biot., vol. 79, pp. 379-388, 2008. 
[24] Q. Deng, X. Li, J. Zuo, A. Ling, and B. E. Logan, "Power generation using an activated carbon fiber felt cathode in an upflow microbial fuel cell," J. Power Sources, vol. 195, 2009.

[25] A. Ter Heijne, H. V. M. Hamelers, V. De Wilde, R. A. Rozendal, and C. J. N. Buisman, "A bipolar membrane combined with ferric iron reduction as an efficient cathode system in microbial fuel cell," Environ. Sci. Technol., vol. 40, pp. 5200$5205,2006$.

[26] Kenrick Vezina, “'Plant Lamps' Turn Dirt and Vegetation into a Power Source MIT Technology Review," november 23 , 2015. .

[27] S. PJ and K. Mohanty, "Epipremnum aureum and Dracaena braunii as indoor plants for enhanced bio-electricity generation in a plant microbial fuel cell with electrochemically modified carbon fiber brush anode.," J Biosci Bioeng, vol. 126, no. 3, pp. 404-410, 2018.

[28] B. Liu, M. Ji, and H. Zhai, “Anodic potentials, electricity generation and bacterial community as affected by plant roots in sediment microbial fuel cell: Effects of anode locations," Chemosphere, vol. 209, pp. 739-747, 2018.

[29] Y. Hubenova and M. Mitov, "Conversion of solar energy into electricity by using duckweed in Direct Photosynthetic Plant Fuel Cell,” Bioelectrochemistry, vol. 87, pp. 185-191, 2012.

[30] M. Helder et al., "Electricity production with living plants on a green roof: environmental performance of the plant-microbial fuel cell," BIOFPR, vol. 7, no. 1, pp. 52-64, 2013. 
[31] R. Moliner, H. Marsh, and E. Heinz, “Del carbón activo al grafeno : Evolución de los materiales de carbono," in Grupo de conversion de combustibles. ICB-CSIC |, 2016, pp. $2-5$.

[32] Richard Martin, "El carbón activo ya se fabrica con una estructura diseñada a medida | MIT Technology Review," 12 junio, 2015. .

[33] P. N. Omo-Okoro, A. P. Daso, and J. O. Okonkwo, "A review of the application of agricultural wastes as precursor materials for the adsorption of per- and polyfluoroalkyl substances: A focus on current approaches and methodologies," Environ. Technol. Innov., vol. 9, pp. 100-114, 2018.

[34] K. N. Palansooriya et al., "Impacts of biochar application on upland agriculture: A review," J. Environ. Manage., vol. 234, no. December 2018, pp. 52-64, 2019.

[35] Green Power "ECO FRIENDLY TECHNOLOGY," "El uso de carbón vegetal como fertilizante," 27 july, 2018 . .

[36] C. Jacobo Mendez Alzamora Consultor Eco-Agricultura. (PGSJ), "Carbón en Agricultura - Engormix,” 11 septiembre, 2017. .

[37] C. Yuan, S. Feng, Z. Huo, and Q. Ji, "Effects of deficit irrigation with saline water on soil water-salt distribution and water use efficiency of maize for seed production in arid Northwest China," Agric. Water Manag., vol. 212, no. September 2018, pp. 424-432, 2019.

[38] J. Kamcev et al., "Author's Accepted Manuscript Salt Concentration Dependence of Ionic Conductivity in Ion Exchange Membranes," J. Memb. Sci., vol. 547, no. October 2017, pp. 123-133, 2017. 
[39] Mathew N.O. Sadiku; Chales K. Alexander, fundamentals oF Electric Circuits, Third Edit., vol. 91. Bookman, 2017.

[40] W. E. Cotching and I. Kögel-Knabner, "Organic matter in the agricultural soils of Tasmania, Australia-A review A R T I C L E I N F O,” Geoderma, vol. 312, no. October 2017, pp. 170-182, 2018.

[41] J. Frouz, "Effects of soil macro- and mesofauna on litter decomposition and soil organic matter stabilization," Geoderma, vol. 332, no. September 2017, pp. 161-172, 2018.

[42] S. Rostami and A. Azhdarpoor, "The application of plant growth regulators to improve phytoremediation of contaminated soils: A review," Chemosphere, vol. 220, pp. $818-827,2019$.

[43] R. Piyare, A. L. Murphy, P. Tosato, and D. Brunelli, "Plug into a Plant: Using a Plant Microbial Fuel Cell and a Wake-Up Radio for an Energy Neutral Sensing System," Proc. - 2017 IEEE 42nd Conf. Local Comput. Networks Work. LCN Work. 2017, pp. 18-25, 2017.

[44] G. Atzori, S. Mancuso, and E. Masi, "Seawater potential use in soilless culture: A review," Sci. Hortic. (Amsterdam)., vol. 249, no. January, pp. 199-207, 2019.

[45] S. Yang, Z. Wang, Z. Han, and X. Pan, "Performance modelling of seawater electrolysis in an undivided cell: Effects of current density and seawater salinity," Chem. Eng. Res. Des., vol. 143, no. 1037, pp. 79-89, 2019.

[46] CANNA Research, "Influencia de la temperatura ambiental en las plantas | CANNA España," 15 de marzo, 2017. . 
[47] O. O. Olubode, "Influence of seasonal variability of precipitation and temperature on performances of pawpaw varieties intercropped with cucumber," Sci. Hortic. (Amsterdam)., vol. 243, no. February 2018, pp. 622-644, 2019.

[48] R. Sánchez-Lucas, R. Fernández-Escobar, M. P. Suárez, M. Benlloch, M. BenllochGonzález, and J. M. Quintero, "Effect of moderate high temperature on the vegetative growth and potassium allocation in olive plants," J. Plant Physiol., vol. 207, pp. 22-29, 2016.

[49] Javier Vegas, “¿Qué ocurre al regar las plantas con agua caliente? -,” 3 de abril, 2016. .

[50] J. Ni, Y. Cheng, Q. Wang, C. W. W. Ng, and A. Garg, "Effects of vegetation on soil temperature and water content: Field monitoring and numerical modelling," $J$. Hydrol., vol. 571, no. November 2018, pp. 494-502, 2019. 